
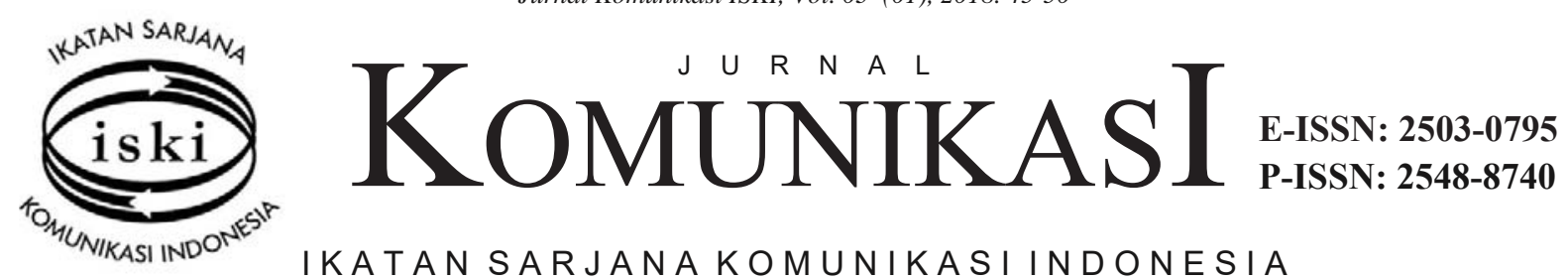

IKATAN SARJANA KOMUNIKASIINDONESIA

\title{
Creating and Utilizing UGC Through Social Media in Trip Planning
}

\author{
http://dx.doi.org/10.25008/jkiski.v3i1.118
}

\author{
Helga Liliani Cakra Dewi ${ }^{1}$ and Reny Yuliati $^{2}$ \\ ${ }^{1,2}$ Universitas Multimedia Nusantara \\ J1. Scientia Boulevard, Gading Serpong, Tangerang 15811, Indonesia \\ 1'helga.liliani@umn.ac.id, ${ }^{2}$ reny.yuliati@umn.ac.id
}

\begin{abstract}
This study aims to understand the behavior of social media users in creating and utilizing User Generated Content (UGC) in trip planning (before, during, and after the trip), and to inform which social media that is mostly used by users. Through understanding the behavior of social media users in creating and utilizing UGC, this reaearch is expected to contribute to the tourism organization in formulating promotion strategies in social media effectively. A survey is conducted to collect research data from 180 of communication students. This research found that Instagram (used by $96.7 \%$ of respondents) and Kaskus (used by $6.7 \%$ of respondents) have significant influence towards users in utilizing and creating the UGC in trip planning.
\end{abstract}

Keywords: User Generated Content, Social Media, Tourism

\begin{abstract}
Abstrak
Penelitian ini bertujuan untuk mengetahui perilaku pengguna media social dalam memanfaatkan dan menciptakan User Generated Content (UGC) dalam melakukan perencanaan perjalanan (sebelum, ketika, dan setelah perjalanan). Selain itu, penelitian ini juga ingin mengetahui media sosial yang paling sering digunakan oleh pengguna dalam memanfaatkan dan menciptakan UGC. Dengan memahami perilaku pengguna media sosial dalam menggunakan dan menciptakan UGC, penelitian ini diharapkan dapat berkontribusikan kepada organisasi pariwisata dalam merencanakan strategi promosinya dengan efektif. Sebuah survey kepada 180 orang mahasiswa Ilmu Komunikasi telah dijalankan untuk menghimpun data penelitian. Penelitian ini menemukan bahwa Instagram (digunakan oleh 96,7\% respponden) dan Kaskus (digunakan oleh 6,7\% responden) memiliki pengaruh yang signifikan kepada pengguna dalam memanfaatkan dan menciptakan UGC untuk merencanakan kegiatan wisata.
\end{abstract}

Kata kunci: Konten yang Dihasilkan Pengguna, Media Sosial, Pariwisata

Copyright @ 2017 Ikatan Sarjana Komunikasi Indonesia. All rights reserved

\section{Introduction}

The emergence of social media brings significant impact toward business. Social media has the ability to reach public massively, fast and also mutually allowing social media to be used by any business organizations to run their promotion activity and to communicate with its public. Nowadays, the digital world enables business organizations to reach its public effectively through social media. With the right strategy and tactic to define the exact audience, social media offers an effective way in reaching the public.

Recently, tourism industry has become one of business that has been intense to perform their promotion activity in social media. Tourism industry is not enough by only using traditional marketing as 
the strategy to promote their business. According to Kaplan and Haenlein (2010) Social media is a group of internet-based applications that build on the ideological and technological foundations of Web 2.0 and that allow the creation and exchange of User Generated Content. With creation and exchange of User Generated Content (UGC) within social media, it has become a new medium for society to get any information needed via Internet.

According to Akehurst (2009), travelling is immensely easier since travellers are now having command online resources that allow research on possible destinations, accommodation, attractions, transportation, and leisure activities. Online platform also enables to purchase the online tourism products and services by the travellers. Since promotion activities and tourism products and services can be purchased through online, this certainly brings many possibilities and opportunities for tourism industry to expand and develop its business.

Various kinds of social media, such as Youtube, Facebook, Instagram, and Twitter are social media that are commonly used by organization to build communication to its public. This kind of thing also happens to tourism organizations, they utilize social media to promote the destination, culinary, and other tourism attractions through UGC.

Indonesian Press Association defines UGC as any content created and or published by cyber users, including articles, images, comments, sounds, videos, and various forms of uploads media attached to cyber media, such as blogs, forums, reader or audiences comments. According to the definition, UGC is adequate to fulfill information needs of social media user, because its features allow user to communicate within articles, images, comments, and also enable to get immediate feedback. Social media users will easily get the information they need by accessing their social media account. Comprehensiveness of information obtained by social media users makes UGC has a significant influence in a communication process in social media.

A study conducted by Compete Inc. has found that UGC is able to give contribution to total 10 billion USD in online travel booking and $20 \%$ of travellers relying on UGC in trip planning (Sarks, 2007). A research undertaken by Google projected that $84 \%$ of travellers have used the Internet in trip planning (Torres, 2010). These data showed that UGC plays an active role in shaping traveller's traveling decision rather than traditional travel agent. UGC is considered as credible sources because it is projected the real experiences shared by social media users. Therefore, UGC in social media has strong influence to generate destination awareness and subsequent decision in choosing travelling destination.

Ridwan Kamil, the Major of Bandung, a Capital City of West Java, Indonesia also uses its social media account to create UGC. Through his Instagram account having 6,7 million followers, he promotes Bandung as a wonderful travel destination. Not only as a travel destination, but Kamil also promotes Bandung's culinary, nature, hospitality, and tourist attractions. City's tourism advancement does bring a broad impact toward its economic advancement. It is clear that the main purpose of the city in advancing the tourism is to improve its economic sector.

The Organisation for Economic Cooperation and Development (OECD, 2007) stated three basic requirements of UGC; first, it needs to be published on a website or on a social networking site that publicly accessible; second, it needs to be contained by creative content; and lastly it needs to be produced outside of professional routines and practices. Nowadays many of young people create UGC in their social media in a creative way, showing their interest and personal preference, such as culinary, travel, fashion, beauty, and so on. They do not only take a picture or video to be posted on their social media, but also they creatively create the UGC with relevant caption or information that might be needed by their followers. This made UGC they have created to gain many likes, comments, and reaction from their followers. Hence, UGC is considered to be one of medium levels with high engagement in order to create relationship with public.

The Government of Busan also found that UGC is a great way to promote tourism activity in Busan. Through its official Instagram account, Busan does not only promote the city, but also its culture, festivals, culinary, and the spirit of Busan. One of promotion programs held by Busan is to invite all of the foreigners living in Korea who has more than 300 hundreds of followers in their social media to travel around Busan for three days and two nights sponsored by the government. The participants are asked to upload some photos or videos during travelling. With this way, the Government of Busan has managed to generate people creating UGC in their social media in order to promote Busan city.

It showed that UGC has been played an important role in tourism organization both in public and private. According to Werthner and Ricci (2004), 
tourism has been ranked as the most leading industry in term of volume of Internet. The Internet itself has become one of the most important channel in tourism industry to run their marketing communication activity (Wang and Fesenmaier, 2006). Nevertheless, social media users as UGC creator are freely either to create a content or drop a comment in the other content, it means that UGC has uncontrolled nature. Tourism organization has to understand how to utilize UGC in a strategic and right way. Therefore, it is important for tourism organizations to be able to understand the behavior of social media users in producing or utilizing UGC in order to get the information, particularly about tourism or leisure activity.

Consumer behavior in social media is rapidly changing. Consumers or users are active in online activities, such as consuming online information, taking part in discussion, and sharing knowledge and experiences with the other users. They also give some contributions to other user's online activity and decision-making process through Internet (Heinonen, 2011). Therefore, understanding the behavior of social media users becomes important for tourism organizations in determining strategies to promote the destination or tourism activity.

This study aims to understand the behavior of social media users in creating and utilizing UGC in trip planning (before, during, and after the trip), and to inform which social media that is mostly used by users. Through understanding the behavior of social media users in creating and utilizing UGC, this research is expected to contribute to the tourism organization in formulating promotion strategies in social media effectively.

\section{Theoretical Framework}

\section{Social Media and Tourism}

Social media is inseparable issue in the current communication technology era. Social media refers to online community that allows people to get involved in decision-making process about how a thing can be done (participatory), allows people to interact with each other (conversational), and the interaction is free in conveying an aspiration (fluid) (Tuten, 2008:20). Referring to AIDA (Awareness, Interest, Decision, and Action) concept to describe consumer behavior, where Action is related to purchase activity, while in social media, the consumer behavior does not stop on Action. In social media, the consumer behavior process is known as
AIDAT, Awareness, Interest, Decision, Action, and Tell (Charlesworth, 2015:18). Social media technology enables people to create and share the content with many users and this activity is known as UGC (Kaplan and Haenlein, 2010). Therefore, as a communication medium, the usefulness of social media is not limited only as a socialization medium of its users, but also has been utilized by marketing communications, politics, educations, and tourisms.

Recently, UGC in social media has become an important information source for tourists (Xiang and Gretzel, 2010). Various things can be informed easily, such as experience or knowledge of a particular tourist area. Tourist's experience is an intangible thing, therefore recommendation of a person is very important for others in deciding their travelling activity (Buhalis, 1998). UGC allows the users to gather the information about tourism and it also helps user in shaping their decision through social media.

\section{Media Richness Theory}

Media Richness Theory by Daft and Lengel (1986) is a theory discussing how the difference of characteristic of communication mediums in influencing communication signal is. The ground assumption of this theory is each communication mediums has level of media richness based on its capacity in facilitating the similarity of meaning in particular time. Daft and Lengel determined four factors measuring the level of media richness that include (1) the ability of the medium to transmit the various signals, such as gesture and facial expression, (2) feedback, (3) message complexness, such as the ability to deliver a more detailed message in a better way, and (4) the ability to build personal relationship.

According to Media Richness Theory, social media has quite high media richness. Firstly, social media has the ability to send various types of information such as text messages, pictures, video and emoticon, this helps to improve the accuracy in sending the message and reduce multi-interpretation by the receiver. Secondly, social media also has an immediate feedback due to sync-based media or can be sent and received in real-time. Thirdly, social media can be used as a medium to connecting people and to build personal relationship between users

\section{Consumer Behavior on Social Media}

The behavior change of online users or consumers need to be updated by companies in order to sustain the communications and engagement with 
their public, particularly in social media. According to Heinonen (2011) consumers are taking part in various online activities. Through online, they are consuming content, participating in discussion, and sharing knowledge with other consumers. These activities are contributing to other consumer's decision-making and activities. Consumers in social media are projected to be actively contributing to the marketing content. They are creating UGC in social media on various sites, such as YouTube, Instagram, Twitter, and Facebook.

The motivations of consumers for engaging in social media are information, entertainment, and social aspect (Heinonen, 2011). Consumers are likely to have only one motivation for visiting a UGC site, however sometimes the motivation was a combination of two or three. Therefore, before entering a UGC site, consumers have their own motivation, such as to find specific information they are looking for, to be entertained, or to be connected with their social circle. UGC indicates play an important role in delivering information and experiences to the users. Users share their knowledge and experiences by creating a UGC, which have an important role in directing decision-making.

\section{Material and Methodology}

A survey is conducted to collect research data. 180 communication students of $\mathrm{XYZ}$ University in Indonesia are volunteers to be involved in this research, and they are required to answer the questionnaire. The questionnaire is divided into three sections, each section aims to analyze the pre-trip, during-trip and post-trip phases of trip planning process.

Reliability analysis also has been performed in this research to measure the scores from instrument are stable and consistent. The questionnaire contains statement that has been measured with seven-liker scale (strongly disagreestrongly agree).Twenty-two items are reliable as the measurement in this research, projected by .951 of Cronbach's Alpha value.

The questionnaire also provides list of social media used by respondents in accessing a UGC. This research is including Instragram, Facebook, Twitter, and Snapchat, social media which are used globally, and also Path, Line, Whatsapp, and Kaskus, social media which popularly used in Indonesia. They also asked to mention the name of social media they used if it is not mentioned in the list before. Therefore, the most used social media in creating and utilizing a UGC is also known through this research.

\section{Result and Discussion}

\section{Pre-trip Phase}

This research found that social media users are actively using social media and utilizing UGC in pre-trip phase in trip planning. It shows that $53.8 \%$ respondents agree that they get related information about the destination by accessing social media. Moreover, with information they have from social media, they are interested to visit the destination. The result also indicates that respondents are likely to have the information about destination and travel activity through their online activity in social media. This result has strengthened previous research conducted by Torres (2010), which projected that 84 percent of travellers used the Internet as a planning resource.

In addition, social media users also assess that information they have had from social media is quite reliable to be their consideration in trip planning. Moreover, they also stated that they do the trip planning based on the recommendation they have found in social media. Along with this result, Jeng and Fesenmaire (2002) stated that travelers generally gather and review various form of travel information prior travel decision-making process in order to avoid making wrong decision.

This research found that Instagram, Path, and Kaskus have significant influence in decisionmaking process. This decision-making process includes the choice on possible destination, accommodation, transportation, and leisure activities. Instagram and Path have similar features in term of information sharing. Both of them enable social media users to share picture and video along with its caption, comment, mention to other users, and chat. Nevertheless, Instagram has "Instagram Live" feature that allows users to share their experience to other users in real time, which this feature is missing in Path.

Moreover, Kaskus is Indonesian Internet forum which is the largest Indonesian online community. Kaskus is very popular with its forum known as "hot thread" created by the community. Within the forum, Kaskus community members are allowed to share any information or experiences by creating the "hot thread" and also they are welcomed to drop comments, this has made Kaskus has high interactivity, credibility, and engagement as a social media.

\section{During-trip Phase}


Shao (2009) defined three main types of consumer's social media activities-- consumption, participation and contribution. In the during-trip phase, social media users are participating and contributing in creating UGC. This research also found that $50.2 \%$ of social media users are uploading their photos or video during travelling on their social media account. They are also likely to add some information about travel activities that they have uploaded based on their real experiences.

Moreover, based on the result, information and recommendations, social media users have found in UGC are meeting their expectation. According to Tussyadiah (2011), travel consumers would generate purchase intention if they find a similar output of consumption to their previous positive consumption experiences. This could generate UGC credibility to be traveller's resource in trip planning, especially if they also participating in creating UGC to share the information and experiences they have had during the travel activities.

In addition, Instagram, Facebook, Twitter, and Kaskus have significant influence in the duringtrip phase of travel. As the most used social media, Instagram has the most significant influence than others. Since the users creating UGC in the travel period, their posting also could generate other users to utilize the UGC they were created.

The result shows that Kaskus has significant influence in the during-trip phase. Like mentioned before, Kaskus community members share the information, experience and knowledge about something through a forum named "hot thread". In the "hot thread", the users are either only utilizing UGC or creating and utilizing UGC at the same time. In addition, Facebook and Twitter are projected to have significant influence in the during-trip phase, while in the pre-trip phase they do not show significant influence. This result shows that social media users are likely to creating UGC in Facebook and Twitter but not to utilizing UGC through them.

\section{Post-trip Phase}

The post-trip phase also found that Instagram, Facebook, Twitter, and Kaskus shows significant influence in this phase. Not only in the during-trip phase, but also in the post-trip phase, users are likely to creating and utilizing UGC in those social media. Furthermore, $50 \%$ of users in post-trip phase are still posting their photos or videos even after the trip is over. They also like to share some recommendations related to their travel experiences through social media.
According to Pan, MacLaurin, and Crotts (2007), social interaction and sharing life experiences are two main factors that are motivating users to create UGC. Besides sharing about travel experiences, social interaction also appeared in the form of giving some comments and insight to others UGC. The post-trip phase is a crucial phase where tourism organizations have to put their concern to actively monitor the UGC. Besides that, tourism organization also suggests to maintain the relationship to its distinguished public or influencer. This because when users create UGC based on their experiences the UGC will become a recommendation to other users. Moreover, the UGC could shape other users decision in trip planning.

\section{Conclusion}

Nowadays, tourism plays an important role in country income. According to Indonesia Tourism Board (2016), since 2013 until 2016, tourism in Indonesia has become the top-four rank of country's income behind oil and gas, coal, and crude palm oil. Indonesia Tourism Minister stated that Indonesia is even more serious to build tourism sector. The Minister has targeted 15 million international tourist visiting Indonesia in 2017. In order to reach the target, social media plays a significant role to tell people about tourism.

This research shows that users are using social media to gain information about destinations, attractions, transportations, and travel activities. They are utilizing UGC in trip planning. Users do some research about destination and arrange the travel itinerary based on the recommendation they found in social media. This shows that UGC influences users in decision-making process of trip planning. Moreover, in during-trip phase and posttrip phase, users are creating UGC with posting their photos or videos based on their experiences. However, they still need to be encouraged to include some information or caption of the UGC.

Instagram is the most used social media by $96.7 \%$ respondent in utilizing and creating UGC in trip planning. According to media richness theory, social media has quite high media richness. Instagram as the most used social media by users provides some features that allow users to send various types of information, it also allow users to have immediate feedback, and the ability to connecting people. This could be the reason on why users are creating and utilizing Instagram in trip planning. 
In addition, this research found that Kaskus is the most Indonesian largest online community used by only $6.7 \%$ of respondent, but it has significant influence to users in pre-trip phase, during-trip phase, and post-trip phase. While Facebook and Twitter have significant influence in during, posttrip, and Path in pre-trip phases. It showed that consumer behavior on social media is not only using social media as information source, but also creating the information in social media to tell people about their experiences.

It shows that users are active in creating UGC in Instagram, Facebook, Twitter, and Kaskus, but only utilizing UGC through Instargam, Path, and Kaskus. This may give some recommendations to tourism organizations to set their online strategy in order to generate users in utilizing and creating UGC through social media.

\section{References}

Buhalis, D. 1998. Strategic Use of Information Technologies in the Tourism Industry. Tourism Management. Vol.19 No. 5:409-421.

Charlesworth, Alan. 2015. An Introduction to Social Media Marketing. New York: Routledge.

Daft, R.L. \& Lengel, R.H. 1986.Organizational Information Requirements, Media Richness and Structural Design. Management Science. Vol. 32:554-571.

Heinonen, K. 2011. Consumer Activity in Social Media: Managerial Approaches to

Consumer's Social Media Behavior. Journal of Consumer Behavior. Vol. 10:356-364.

Indonesia Tourism Board. 2016. Viewed 18 October.

https://web.kominfo.go.id/sites/default/files/Paparan

\%20Kemenpar\%20untuk\%20KIDI\%202016.pdf

Jeng, J. \& Fesenmaier, D. R. 2002.

Conceptualizing the Travel Decision-Making
Hierarchy: A Review of Recent Developments. Tourism Analysis Vol. 7 No. 1:15-32.

Kaplan, A.M., \& Haenlein, M. 2010. Users of the World, Unite! The Challenges and Opportunities of Social Media.Business Horizon Vol. 53 (59-68).

OECD. 2007. Participative Web and UserCreated Content: Web 2.0, Wikis, and Social Networking. Paris: Organisation for Economic Cooperation and Development.

Pan, B., MacLaurin, T., Crotts, J. 2007. Travel Blogs and Their Implications for Destination Marketing. J Travel Res Vol. 46 No.1:35-45.

Sarks, G. 2007. Consumer Generated Content in Travel: A Roadmap for Bringing Consumers into the Conversation. Web Seminar Presentation, 16 April. Compete, Inc.

Shao, G. 2009. Understanding the Appeal of User-Generated Media: A Uses and Gratification Perspective. Internet Research Vol. 19 No. 1:7-25.

Torres, R. 2010. Today's Traveler Online: 5 Consumer Trends to Guide Your Marketing Strategy. Travel Distribution Summit: Chicago.

Tussyadiah, I., \& Park, S., \& Fesenmaier, D. R. 2011. Assessing the Effectiveness of ConsumerNarratives for Destination Marketing. Journal of Hospitality \& Tourism Research Vol. 35 No. 1:64-78.

Tuten, T. L. 2008. Advertising 2.0. Social Media Marketing in a Web 2.0 World. Westport: Praeger.

Wang, Y., \& Fesenmaier, D. R. 2006. Identifying the Success Factor of Web-Based Marketing Strategy: An Investigation of Conventional and Visitors Bureau in the United States. J Travel Res Vol. 44 No. 3:239-249.

$\mathrm{f}$ H., \& Ricci E.2004. E-Commerce and Tourism. Commun ACM Vol. 17 No. 12:101-105.

Xiang Z. \& Gretzel U. 2010. Role of Social Media in Online Travel Information Search. Tourism Management Vol. 31 No. 2:179-188. 